\title{
The IOC and Olympic bids from democracies and authoritarian regimes - A socioeconomic analysis and strategic insights
}

\author{
Thomas Könecke ${ }^{1, *} \&$ Michiel de Nooij ${ }^{2}$ \\ 1 Department of Sport Economics, Sport Sociology and Sport History, Johannes Gutenberg University Mainz, Mainz, Germany \\ 2 Michiel de Nooij Economic Research and Advice, Amsterdam, The Netherlands \\ * Corresponding author: PD Dr. Thomas Könecke, Faculty of Social Sciences, Media, and Sport, Department of Sport Economics, Sport Sociology, \\ and Sport History, Johannes Gutenberg University Mainz, 55099 Mainz, Germany, Phone: +49 61313923589 \\ E-mail: koenecke@uni-mainz.de
}

\section{ORIGINAL ARTICLE}

\section{Article History:}

Submitted $8^{\text {th }}$ August 2017

Accepted 20 ${ }^{\text {th }}$ October 2017

Published 12 ${ }^{\text {th }}$ December 2017

\section{Handling Editor:}

Otmar Weiß,

University of Vienna, Austria

Editor-in-Chief:

Martin Kopp

University of Innsbruck, Austria

\section{Reviewers:}

Reviewer 1: Jean-Loup Chappelet, University of Lausanne, Switzerland Reviewer 2: Robert Kaspar, Private University Schloss Seeburg, Austria

\section{ABSTRACT}

This socio-economic study scrutinizes the bidding process for an Olympic Games in democratic countries and authoritarian states. More specifically, transaction cost economics is employed as a lens to analyse the bidding processes for the Winter Olympic Games in 2022 and the Summer Games in 2024 and 2028. Against the backdrop of these case studies, it becomes obvious that recent developments result in serious problems for the IOC, which is why the organization has to keep a certain strategic proximity to authoritarian states. This measure can be considered an insurance policy because of the high and likely sunk ex ante transaction costs that characterize bids from democratic countries. It will become apparent that keeping good working relations with authoritarian governments helps the IOC to secure the future of its main revenue driver, the Olympic Games, thus providing for its own future. Furthermore, the IOC's decision to include the Summer Olympic Games in 2028 in the bidding process originally geared towards the Games in 2024 will be outlined as a logical consequence of the developments that are analysed in this study. This strategic move will turn out to be a logical consequence of the developments that are analysed in this paper.

Keywords:

Olympic bid - mega event - bidding process - transaction cost economics - ex ante costs - 2022 $2024-2028$

Citation:

Könecke, T. \& de Nooij, M. (2017). The IOC and Olympic bids from democracies and authoritarian regimes - A socioeconomic analysis and strategic insights. Current Issues in Sport Science, 2:009. doi: 10.15203/CISS_2017.009

\section{Introduction}

Staging the International Olympic Committee's (IOC) flagship event, the Olympic Games, has undergone a drastic demise in popularity as can be seen by the high number of potential host cities that dropped out of the bidding process for the Games in 2022 and 2024/28. In the bidding race for the Winter Games in 2022, all eight potential hosts from democratic countries terminated their bidding efforts before the IOC's final vote, which left two cities from authoritarian states as potential hosts: Almaty
(Kazakhstan) and Beijing (China). Both countries, Kazakhstan and China, are linked to issues such as human rights violations and lacking freedom of press, which is why some do not consider either one an ideal location for an "event that aims for global community and inclusiveness" (Barrabi, 2015). The current bidding process for the Summer Games in 2024 has also suffered from unfavourable referenda and withdrawn bids. Only two of a total of seven cities have prevailed: Los Angeles (USA) and Paris (France), both of which are located in western democracies. Most likely motivated by the fleeting interest in 
staging Olympic Games especially in democratic countries, the IOC has just recently decided to not only award the 2024-Summer Games in the current bidding process, but to include the Games in 2028 as well. Thus, neither Paris nor Los Angeles has to be refused as Olympic host.

One major factor that differentiates these bidding processes from prior ones is the fact that referenda have become a common tool to examine the public's support in many countries. From stakeholder theory (Clarkson, 1995; Donaldson \& Preston, 1995; Freeman, 2008) it is clear that public support is a major asset for countries and regions interested in bidding for and staging a mega sport event because the general public and especially local residents are key stakeholders for such endeavours (Preuss, 2008, 2013; Preuss \& Solberg, 2006). But contrary to what could be expected from past research (Atkinson, Mourato, Szymanski, \& Ozdemiroglu, 2008; Barget \& Gouguet, 2007; Heisey, 2009; Heyne \& Süssmuth, 2007), almost all of the referenda turned out dismissive in the bidding processes for 2022 and $2024 / 28$. And even after the only supportive referendum in Oslo (Norway) the bid was terminated prematurely for political reasons at a later point in time. Political concerns have also ended bids in other democracies in both bidding processes. Overall, thirteen of the originally seventeen cities that had somewhat audibly declared interest in staging the Olympic Games in 2022 or $2024 / 28$ and/or held a referendum on that matter dropped out before the IOC's vote on the host. In total, six referenda were held and eight bids were terminated without referendum or after a confirmative one because of political concerns. But contrary to the many bids from democratic countries that did not outlast the challenges of the bidding process, the two cities from authoritarian states both maintained their bids until the $I O C$ cast its final vote.

In this socio-economic study, the bidding processes for the Winter Olympic Games in 2022 and the Summer Games in 2024 and 2028 serve as case studies to scrutinize the decisions linked to the bidding process in democratic countries and authoritarian states. Transaction cost economics is employed as a lens to outline the problems that the findings pose for the IOC and to understand why the organization has to keep a certain proximity to authoritarian states for strategic reasons. This measure can be considered an insurance policy because of the high and likely sunk ex ante transaction costs that characterize bids from democratic countries. It will become apparent that keeping good working relations with authoritarian governments helps the IOC to secure the future of its main revenue driver, the Olympic Games, thus providing for its own future. Furthermore, the IOC's decision to include the Summer Olympic Games in 2028 in the bidding process originally geared towards the Games in 2024 will be outlined as a logical consequence of the developments that are analysed in this study. This strategic move will turn out to be a logical consequence of the developments that are analysed in this paper.

The paper is structured as follows: In the next chapter, transaction cost economics is briefly introduced. Afterwards, the case studies of the bidding processes for 2022 and 2024/28 are presented. In the first part of the chapter, general background information is provided, the second part outlines specific aspects that are relevant for the scope of this paper. In the following chapter, the decisions and developments that are typical of democratic and authoritarian countries during a bidding process for Olympic Games will be contrasted. The final chapter provides a discussion and reviews some of the IOC's recent strategic decisions against the background of the findings of this paper.

\section{Transaction cost economics}

Transaction cost economics focus on costs caused by different types of transactions. The basis of such transactions are relations between the concerned actors that can be understood as implicit or explicit contracts. All complex contracts are invariably incomplete because it is impossible to incorporate (satisfactory) solutions for all possible future developments already at the time of the initiation of a contract (Klein, 1998, pp. 13-14). This incompleteness can be attributed to bounded rationality, i.e. the inability of the involved parties to have access to and take into account all information that could possibly be relevant for the contract (limited information) as well as a limited decision time. Furthermore, opportunistic behaviour by one or more of the parties involved can be or can become a factor (Sam, Batty, \& Dean, 2005, pp. 5-6).

As Williamson points out, transaction costs of various types exist. There are the initial or "ex ante costs of drafting, negotiating and safeguarding an agreement" (Williamson, 1994, p. 103). Due to the incompleteness of contracts there are also "the ex post costs of maladaptation and adjustment that arise when contract execution is misaligned as a result of gaps, errors, omissions, and unanticipated disturbances" (ibd.), e.g. opportunistic behaviour or other unexpected developments.

This means that contract partners do frequently not operate harmoniously but have to expect delays, breakdowns, and other malfunctions in their transactions. Consequently, the costs of planning, adapting, and monitoring have to be taken into consideration when analysing transactions in order to judge their viability (Williamson, 1981, pp. 552-553). While "[s]ome transactions are simple and easy to mediate. Others are difficult and require a good deal more attention" (Williamson, 1981, p. 553). Especially in the latter type monitoring, repeated negotiations, and enforcement mechanisms will be of high importance. These can be considered "costs" stemming from bounded rationality or the effort to prevent potentially opportunistic behaviour.

If the IOC wants to award an Olympic Games, ex ante and ex post transaction costs are relevant. Ex post costs occur after the host has been chosen and the host contract signed. These include monitoring the preparations for the event or renegotiations of the original agreement (like for Tokyo 2020 where many venues including the main stadium are reconsidered to reduce costs). Furthermore, they obviously occur during the event, but 
also afterwards (for example, when legacy programs are to be implemented, which frequently does happen as expected). Ex ante costs are all efforts invested in the bidding process, such as meetings, negotiations, travels, etc. until a host city contract is finalized. In this analysis, the focus is put on ex ante costs during the bidding process. But it can be assumed that many of our considerations should also be applicable for an analysis of ex post costs occurring after the host has been chosen.

\section{Case studies: The bidding processes for the Olympic Games in 2022 and 2024/28}

\section{Background}

In order to have a realistic chance to succeed, a city's ambition to host Olympic Games has to be supported by the regional and national government, the National Olympic Committee (NOC), and other sport organizations. The support of the latter two is crucial because they have to lobby for the bid and secure support within the "Olympic family". Furthermore, and unlike often expected by the public, the NOC eventually has to nominate the city as "Applicant City" to the IOC. Political support is also crucial because several declarations and guarantees have to be issued by the respective governments and/or administrations. Against this background, the bidding process for the Winter Olympic Games in 2022 can be considered a turning point in the history of the IOC and the Olympic Movement, which is why it will be looked into in the next paragraphs.

As in many earlier bidding processes, being named the national "Applicant City" by the respective NOC was one of the many pitfalls that had to be overcome when a city wanted to host the 2022-Games. Only half of the originally eight potential hosts from Europe attained this status alongside Beijing (China) and Almaty (Kazakhstan). The withdrawals of Zaragoza and Barcelona occurred because of political concerns (Mackay, 2013; Marca.com, 2011). In Munich and Graubünden failed referenda ended the cities' bidding efforts (Könecke, Schubert, \& Preuß, 2016). Thus, the originally very satisfactory number of ten potential hosts had already been reduced to six before the application phase really got going (Figure 1).

The next major step was the submission of the Application File, also called "Mini Bid Book". With the Swedish Applicant City of Stockholm another potential host from Europe withdrew before submitting the file (Figure 1). This decision was taken because of political concerns regarding the cost of the Games. After the submission of the Application Files, the IOC executive board selected the Candidate Cities that would get the opportunity to submit a Candidature File or "Bid Book". Yet, before the nomination of the Candidate Cities, two more cities from Europe left the bidding race: Lviv (Ukraine) withdrew because of the crisis in the country and Krakow (Poland) did so because of yet another dismissive referendum.

As a result, the Norwegian city of Oslo was the only remaining European Candidate City alongside Almaty and Beijing. In Oslo a referendum had yielded a supportive result with 55.1 percent of the voters in favour of bidding (Goddard, 2013). However, the Norwegian national government eventually decided not to back the bid because of financial concerns. Thus, Oslo also withdrew its candidature and did not deliver a Bid Book (Figure 1). Since all European cities had discontinued their efforts before the final decision by the IOC, the Candidate Cities from Kazakhstan and China were left as only possible hosts. Ultimately, the 2022 Winter Olympic Games were awarded to Beijing (Figure 1).

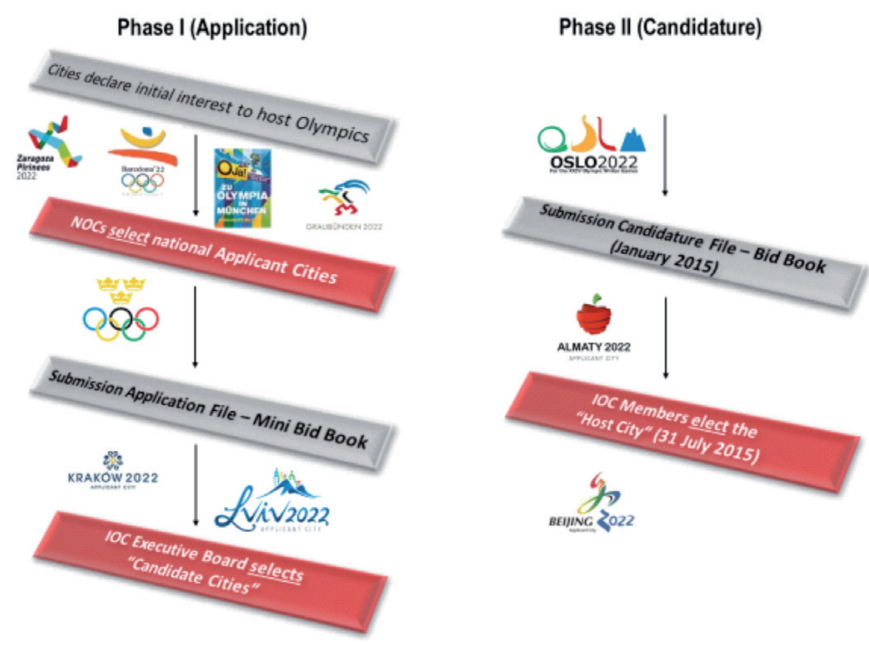

Figure 1: Overview over the bidding process for the 2022 Winter Olympic Games (logos denote at which stage a city left the bidding process or lost the IOC's final election)

In total, four of the potential hosts from Europe conducted referenda on their bids for the 2022 Winter Olympic Games. Three of these were dismissive, immediately ending the bids. Only the referendum in Oslo turned out supportive. But this bid was stopped due to political concerns. Against this background it has to be noted that referenda relating to (bids for) Olympic Games are a rather new phenomenon in most countries and only few prior examples can be found.

Before to the Winter Games in Salt Lake City (Utah) in 2002, a poll yielded a favourable vote (57 percent) in 1989 (Guala, 2009). This referendum to use part of the sales tax revenues for the construction of Olympic facilities was the only one in which US-American citizens could vote during the bidding process (Andranovich, Burbank, \& Heying, 2001). In 1994, there was a successful vote in Atlanta on issuing two bonds for the 1996-Games, whereas the 1978-vote in Los Angeles refused to use city general funds for the Games in 1980. In 1972 voters in a referendum in Denver (USA) voted against making funds available for the 1976-Winter Games, which is why the event was re-awarded to Innsbruck (Austria) (Moore, 2015). These last three referenda were held after the IOC had awarded the Games to the cities. Unlike the referenda during the 2022-bidding process, neither of the US-American referenda concerned the question whether to bid or not. 
In Europe voting on (bidding for) Olympic Games has generally been uncommon, even though Guala (2009) identifies three Swiss referenda with positive outcomes since 1928 (St. Moritz in 1928 and 1948, Sion in 2002) and several others uncertain or clearly against bidding (Valais, Interlaken, Davos). But it has to be kept in mind that referenda are a central element of Swiss democracy, which is why they are also held on sport events. Guala only notes one further European referendum prior to the turn of the century. In 1991, 84.7 percent of the voters in the Italian Aosta Valley - located at the Swiss border - voted against bidding for the 1998 Winter Olympic Games. Furthermore, two supportive referenda were held in Salzburg (Austria) in 1997 (regarding the Winter Games in 2006) and in 2005 (regarding 2014) (News.at, 2006).

The sudden popularity of referenda and their slim chances of turning out successfully as well as the attrition of European cities during the bidding process for the Winter Olympic Games in 2022 was a major motivation for the $\mathrm{OC}$ to restructure the bidding process. This was done as one corner stone of the "Olympic Agenda 2020", "the IOC's strategic roadmap for the future of the Olympic Movement" (International Olympic Committee, 2014). The new bidding process now consists of an "Invitation Phase" that does not include a formal commitment to bid and a "Candidature Phase", which comprises three stages. "Each stage will address different elements of the cities' proposals" (International Olympic Committee, n.d.a) and end with filing the appropriate documents with the IOC. "After each submission, the IOC Executive Board will confirm the transition of the cities to the next stage. [...] Finally, [...] the IOC members elect the host city" (ibd.).

But despite these efforts by the IOC, unfavourable referenda and withdrawn bids continued during the current bidding process for the Summer Olympic Games in 2024/28. In Vienna (Austria) an overwhelming 72 percent of the participants voted against bidding for the Games in 2028 (Crook, 2013; Magistrat der Stadt Wien, 2013) and voters in Hamburg (Germany) declined bidding for the 2024-Games by 52 percent. This even though Germany's NOC had supported Hamburg's bidding ambition over those of Berlin because prior surveys in both cities had shown a higher support in Hamburg (Könecke et al., 2016). Boston withdrew from the bidding race for 2024 because of political concerns and was replaced by Los Angeles as potential US-American host (Dampf, 2016). In Rome, the newly elected mayor Virginia Raggi had opposed the city's bid during the electoral campaign (New York Times, 2016) and put an end to the Olympic ambitions after taking office. Budapest (Hungary) long resisted the calls for a referendum as the city council had decided against holding one. However, a petition for a poll was signed so often that the city council dropped the bid before the referendum took place (Dampf, 2016; Livingstone, 2016; Morgan, 2017). Consequently, only Paris (France) - where the council also had decided against a referendum - and Los Angeles (USA) remained as potential hosts in the bidding process originally geared towards awarding the Summer Games in 2024. Against this backdrop, the IOC decided to award the next Sum- mer Games right away, so that Paris now will host the Games in 2024 and Los Angeles the ones in 2028 (Carroll \& Melander, 2017; International Olympic Committee, 2017).

\section{Relevant observations}

As has been mentioned before, a specificity of the bidding processes for the Olympic Games in 2022 and 2024/28 was a surge in popularity for referenda in Europe. Four of the potential hosts for the Games in 2022 (Graubünden, Krakow, Munich, and Oslo) and two for the Games in 2024/28 (Hamburg and Vienna) conducted referenda, of which only the one in Oslo supported the bid. Furthermore, four of the 2022-bids were withdrawn due to political concerns related to staging the Games (Barcelona, Zaragoza, Stockholm, and Oslo). Even though Lviv (Ukraine) also had to terminate its bid for political reasons, making it the fifth city with this reason in the 2022-bidding race, its withdrawal was not driven by a political unwillingness to stage the event. On the contrary, Lviv had to withdraw because of the violent conflict within Ukraine, which did not allow a continuation of the bid despite an affirmative political climate (Thomson Reuters, 2014), which makes it a very special case. Of the bids for 2024, three were withdrawn because of political concerns (Boston, Rome, and Budapest), whereas Budapest's city council did so to prevent a likely negative referendum. These findings regarding the reasons for not keeping up an initial interest in hosting an Olympic Games are summarized in Table 1. But not only the bids that were prematurely terminated allow interesting insights: At the end of the bidding process for the Games in 2022, all European cities had dropped out and only the Candidate Cities from Kazakhstan and China were left as possible hosts. According to the Economist Intelligence Unit's (EIU) Democracy Index both countries have to be considered authoritarian regimes and are classified as "not free" in terms of political rights and civil liberties in the report "Freedom in the World" (FiW) (Table 1). Since the IOC did not strongly insist during the bidding process, heavy criticism arose because of the countries' "terrible" (Barrabi, 2015) or "extremely poor human rights records" (Human Rights Watch, 2015) and lacking freedom of press due to which neither country was considered an ideal location for an "event that aims for global community and inclusiveness" (Barrabi, 2015) by many.

In the bidding process that was originally geared towards awarding the Olympic Games in 2024, the IOC just recently has taken the self-proclaimed "historic decision" (International Olympic Committee, 2017) of awarding both of the remaining bidders with an Olympic Games (Paris with 2024, Los Angeles with 2028) (Table 1). This decision is most likely spurred by the effort to prevent antagonizing one of the two cities when electing the other one as the host for 2024. This could have meant to lose yet another potential host from a democratic country as future host if the city had decided against another bid. Furthermore, the IOC thus gained four more years before having to conduct the next bidding process for Summer Games. 
Table 1: Overview over the cities interested in staging the Olympic Games in 2022 and 2024/28

\begin{tabular}{|c|c|c|c|c|c|c|c|}
\hline $\begin{array}{l}\text { Bidding } \\
\text { process } \\
\text { for OG in } \\
\ldots\end{array}$ & City & Country & $\begin{array}{l}\text { Freedom in } \\
\text { the World- } \\
\text { report } 2017^{1}\end{array}$ & $\begin{array}{l}\text { Economist } \\
\text { Intelligence } \\
\text { Unit's } \\
\text { Democracy } \\
\text { Index } 2016^{2}\end{array}$ & $\begin{array}{l}\text { In case of } \\
\text { referendum: } \\
\text { Referendum } \\
\text { against bid? }\end{array}$ & $\begin{array}{l}\text { Bid } \\
\text { terminated } \\
\text { due to } \\
\text { political } \\
\text { concerns? }\end{array}$ & $\begin{array}{l}\text { Host City } \\
\text { for Games } \\
\text { in ... }\end{array}$ \\
\hline \multirow[t]{6}{*}{2022} & Zaragoza & Spain & free (94) & 8.3 & & YES & \\
\hline & Barcelona & Spain & free (94) & 8.3 & & YES & \\
\hline & Munich & Germany & free (95) & 8.6 & YES & & \\
\hline & Graubünden & Switzerland & free (96) & 9.1 & YES & & \\
\hline & Stockholm & Sweden & free (100) & 9.4 & & YES & \\
\hline & Lviv & Ukraine & partly free (61) & 5.7 & & YES $^{3}$ & \\
\hline \multirow[t]{4}{*}{. } & Krakow & Poland & free (89) & 6.8 & YES & & \\
\hline & Oslo & Norway & free (100) & 9.9 & NO & YES & \\
\hline & Almaty & Kazakhstan & not free (22) & 3.1 & & & $\begin{array}{l}\text { NOT } \\
\text { elected }\end{array}$ \\
\hline & Beijing & China & not free (15) & 3.1 & & & 2022 \\
\hline \multirow[t]{7}{*}{$2024 / 28$} & Boston & USA & free (89) & 8.0 & & YES & \\
\hline & Vienna & Austria & free (95) & 8.4 & YES & & \\
\hline & Hamburg & Germany & free (95) & 8.6 & YES & & \\
\hline & Rome & Italy & free (89) & 8.0 & & YES & \\
\hline & Budapest & Hungary & free (76) & 6.7 & THREAT $^{4}$ & YES & \\
\hline & Paris & France & free $(90)$ & 7.9 & & & $2024^{5}$ \\
\hline & Los Angeles & USA & free (89) & 8.0 & & & $2028^{5}$ \\
\hline
\end{tabular}

1. total score ranging from 100 (most free) to 0 (least free) with three categories (free - partly free - not free)

2 total score ranging from 10 (highest) to 0 (lowest) (all values rounded to first decimal) with 8-10 (full democracy) - 6-7.9 (flawed democracy) - 4-5.9 (hybrid regime) - below 4 (authoritarian regime)

3 Lviv had to withdraw its bid because of the violent conflict within the country despite the political will to stage Olympic Games.

$4 \quad$ In Budapest a referendum would have been held if the city council had not terminated the bid beforehand.

5 The IOC decided to include the Olympic Games in 2028 in the bidding process for 2024 after all bidders except Paris and Los Angeles had discontinued their bids.

Against the backdrop of the developments in the recent bidding processes in general and the findings summarized in Table 1 in specific, the differences in the bidding processes in democracies and authoritarian states will be analysed hereafter.

\section{Results: The bidding process in democratic and authoritarian countries}

It can be seen in Table 1 that the two hosts for the Olympic Games in 2024 and 2028 and almost all countries which have left any of the observed bidding processes prematurely are labelled as "free" in the FiW-report and classified as (either full or flawed) "democracies" in the EIU's Democracy Index. The only exception is Lviv (Ukraine) which dropped out because of a violent conflict even though the political will still was to host an
Olympic Games. The Ukraine was classified as "partly free" and "hybrid regime", respectively.

As a backdrop for the further analysis it has to be pointed out that the FiW-report assesses "rights and freedoms enjoyed by individuals" (Freedom House, 2017) and the EIU's Democracy Index "is based on five categories: electoral process and pluralism; civil liberties; the functioning of government; political participation; and political culture" (The Economist Intelligence Unit, 2015, p. 44). That means that in each of the countries labelled as democratic and free the opportunity to participate in or influence the political process is fairly good. Institutions and individuals are rather independent of the central government, political opposition is not oppressed, and opinions can be expressed rather freely.

This means that if a city in these democracies considers bidding for an Olympic Games, a general decision to bid has to be taken 
by a sufficiently large number of initial supporters in politics and the sports world in order to initiate a bid. Afterwards, two more major decisions follow: one is whether to hold a referendum, the other is whether to maintain a bid until the final vote by the IOC. As will briefly be illustrated by some examples from the case studies, these "decisions" usually are no singular incidents but processes or series of decisions:

- Munich's city council initially decided to hold a referendum when it voted on entering another bidding race after the IOC's final vote for the 2018-Winter Games had been cast for Pyeongchang (South Korea). Nevertheless, the referendum was not the first step in the bidding process. Its preparation was only one of many actions that were undertaken simultaneously. But its outcome ended all further preparations at once. This is why in Figure 2 only the outcome of a referendum is modelled as "singular decision".

- Budapest's city council voted against a referendum by a tight vote of 16 to 14 . Nevertheless, a journalist kept trying to force a referendum. After failing with this attempt on a national level, she tried it on the city level (Pavitt, 2016). Ultimately, a petition calling for a referendum was signed by many more people than would have been required. As a reaction, the city council withdrew its support for the bid, thus terminating it (Morgan, 2017). Consequently, the decision to hold a referendum in a democratic state in Figure 2 is a process that can be considered latent until the bidding process is either over or the bidder drops out. Theoretically, it could also be possible to hold multiple referenda on a single bid.

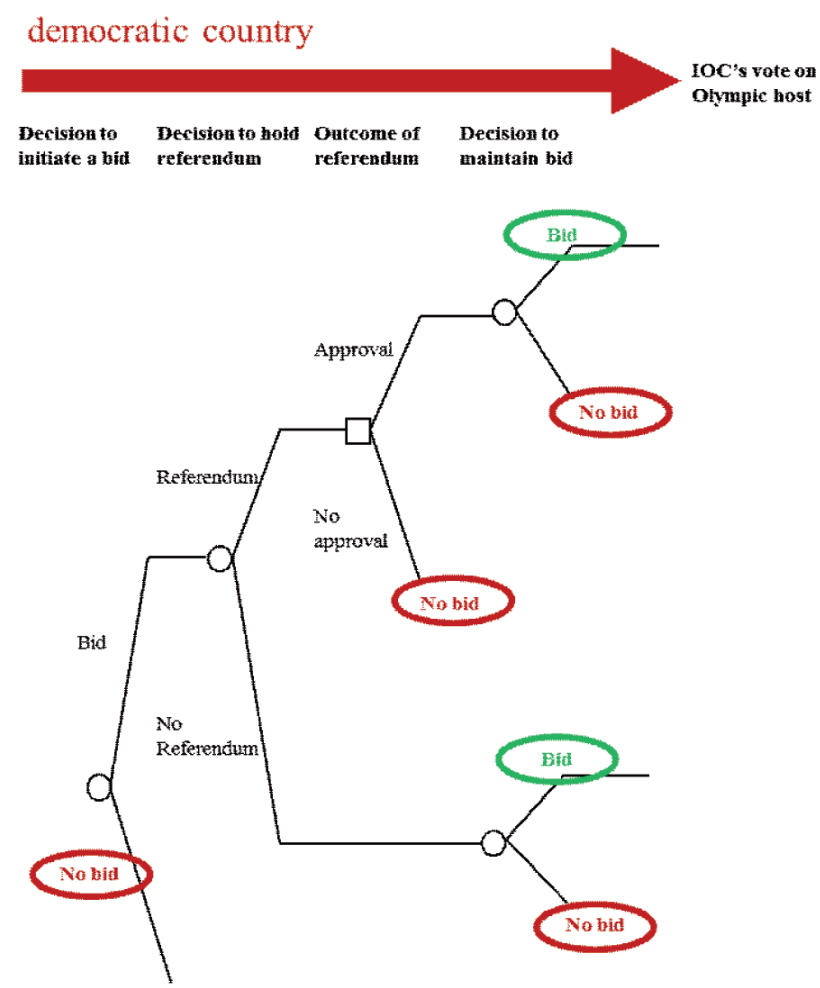

- Oslo's referendum was supportive. Nevertheless, the bid Bid Book was not handed in since the national government refused to cover cost overruns. This shows that even a successful referendum cannot guarantee that a bid will prevail until the IOC's final decision but that the decision to maintain a bid is a political one and an affirmative referendum is just one aspect in this regard (Figure 2).

These remarks emphasize that the decisions depicted in Figure 2 cannot be considered sequential because a referendum can be held at any time during a bidding process and the decision to bid can be overturned at virtually any stage of the bidding process. Consequently, the circles in Figure 2 indicate that the decisions to bid for an Olympic Games, to hold a referendum, and to maintain a bid are lasting processes that involve a multitude stakeholders. Yet, the negative outcome of a referendum - if one is held - immediately finalizes the decision not to bid because it is almost impossible that a politician in a democratic country would act against such a referendum after it were held.

Contrary to the one in democracies, decisions regarding the bidding process in countries that are classified "not free" in the FiW-report and "authoritarian regimes" in the EIU's Democracy Index should be very different. Here, the government is not legitimized by free and democratic elections and individuals, sport organizations, or regional and local governments are not rather independent of a nation's political leadership. This means that if a decision to bid is communicated to the IOC, it is very likely to be upheld for good. External factors within the

authoritarian state

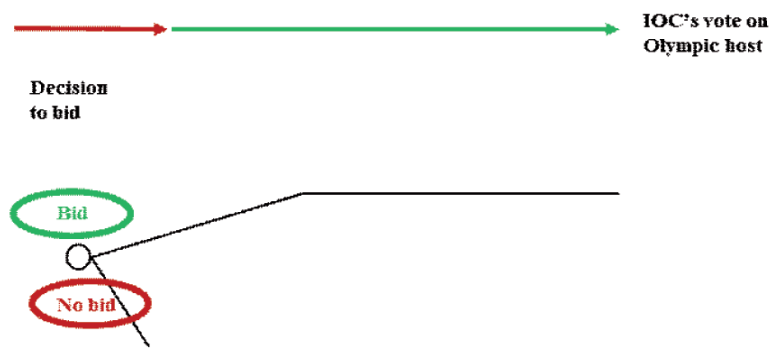

legend:

- colour of arrows denotes degree of uncertainty

$>$ red arrow $=$ high degree of uncertainty

$>$ green arrow $=$ low degree of uncertainty

- thickness of arrows symbolizes number of relevant stakeholders

- circles denote long-lasting decision processes

- squares denote singular decisions

- ovals show outcome of bidding process after depicted decisions

Figure 2: Decisions in a democratic country and an authoritarian state during the bidding process 
country (elections, referenda, and public or political pressure) are not relevant. If compared to the many stakeholders and potential pitfalls in democracies, only a rather small number of decision-makers should be involved in authoritarian states since, for instance, interest groups, local politicians, or office-holders in sport organizations are far less likely to forcefully oppose the central government's decisions. Due to this and much unlike in democratic countries, a bid will meet strong support after it has been decided upon by political leadership. Consequently, the bidding process in authoritarian states only comprises one major decision process involving only a rather small number of relevant stakeholders (Figure 2).

Applying transaction cost economics to the findings summed up in Figure 2, it can be concluded that bids from democracies obviously comprise much higher ex ante transaction costs for the IOC than those from authoritarian states. The development of such a bid is much more uncertain (for example regarding a potential referendum) and it involves many more stakeholders (regional and national politicians, the public, the media etc.) whose behaviour during the process is rather uncertain and can change rapidly. Thus, bids from democratic countries are very costly transactions for the IOC because of long negotiation processes and the high likelihood that all investments on behalf of the IOC become sunk costs. This is the case if a bid of a generally suitable bidder is terminated prematurely (c. $\mathrm{f}$. Klein, 1998, p. 16 who illustrates comparable observations for transactions of a sponsor with a sport organization) and not renewed for future Olympic Games. For instance, this was the case in Munich, where a referendum ended the bid for 2022 after having lost the final vote for 2018. This poll also made future bids from the region highly unlikely for quite some time to come. A similar situation could have occurred in the current process for 2024/28 since Paris was specifically aiming at celebrating the centenary of the 1924-Games in the city and probably would not have run again for 2028 .

Due to the far less complex and insecure process outlined in Figure 2, a bid by an authoritarian state is a much less costly transaction for the IOC as far as the ex ante transaction costs before signing the host contract are concerned. Fewer stakeholders influence the decision, which considerably diminishes negotiation and control costs for the IOC. Furthermore, the likelihood of a premature termination has turned out to be very low if compared to democracies during the bidding process for the Games in 2022.

\section{Discussion}

This study analysed recent developments in the bidding process for Olympic Games. It became obvious, that (western) democracies are far less reliable bidders than authoritarian states and that their bids incur much higher ex ante transaction costs. This observation could be one major strategic motivation for the IOC to actively strengthen its ties to authoritarian governments despite the opposition and detrimental effects on its brand image this generates in democratic countries (Könecke et al., 2016). These effects became obvious when the IOC was left with two authoritarian states as only potential hosts of the Winter Olympic Games in 2022. Like it has been observed in a sport sponsorship context, this caused "intangible costs [due to] an erosion of public goodwill because of the [transaction partners'] image" (Sam et al., 2005, p. 9). In this regard, it has to be taken into account that even beforehand, the IOC had been closely associated with authoritarian states, which seemingly was one reason for the failed referendum in Munich (Könecke et al., 2016). This means that the "perceived loss of autonomy for the sport organisation" (Sam et al., 2005, p. 9) and proximity to authoritarian governments was aggravated by the development of the bidding process.

Against this backdrop, it is interesting to observe the strategy the $I O C$ chose in dealing with another authoritarian transaction partner who violated the following central claim of the organization:

"The IOC's priority is the protection of the clean athletes and to support them on and off the field of play. This means that any investment in the fight against doping and against match-fixing, manipulation of competition and related corruption, whether it be for education, testing, research, logistics or staffing, cannot be considered as a cost but as an investment in the clean athletes" (International Olympic Committee, n.d.c).

Before the Olympic Games in 2016, the McLaren-report had uncovered systematic and government-supported doping of Russian athletes prior to the "home" Winter Olympic Games in Sochi in 2014. But the IOC did not distance itself from the authoritarian government in Russia, thus failing to prove its willingness to be true to its values or emphasizing its independence. Instead, it virtually refrained from banning the Russian team or any of its athletes for the Summer Games in 2016 because it only excluded - or pretended to exclude - Russian athletes who had previously been banned for doping offenses. Since these athletes were punished a second time for their violation, they could appeal to the Court of Arbitration for Sport (CAS) which had deemed this practice as incompatible with the existing regulations and thus invalid in a similar case. IOCpresident Thomas Bach - a lawyer and experienced sports politician - who headed the relevant committee must have been aware of this fact. The general decision on how to deal with those athletes who had not been punished for violating doping regulations before, was delegated to the respective sports' world federations even though these are not formally involved in organizing Olympic Games. This in turn did not only create an uneven treatment of athletes from different sports but had the effect that a vast majority of Russia's Olympic team could participate.

The only permanent "exclusion" of a Russian athlete by the IOC was that the Russian whistle-blower Julia Stepanowa who had contributed to uncovering the fraudulent system was not al- 
lowed to participate in the Games in 2016 under the IOC's neutral flag. This had been her only remaining option because she had not been nominated by Russia's NOC after her defection even though she had met the formal requirements. Having her participate in the Olympics would certainly have been well-received in most democratic countries but would likely have had the opposite effect in Russia - and probably in other authoritarian states. The same would have been true of any kind of actual punishment for the systematic, government-supported doping in Russia.

When facing the strategic question how to deal with the McLaren-report's findings right before the Olympics in Rio, the IOC had to choose between two scenarios: It could either damage its reputation in democratic countries (further) or loose reputation in authoritarian ones. Given that "transaction costs economics tries to explain how trading partners choose, from the set of feasible alternatives, the arrangement that protects their relationship-specific investments at the least cost" (Klein, 1998, pp. 15-16), the question arises, why compromising central values and openly fortifying the perceived dependence on authoritarian regimes - both of which will increase costs for future transactions with democracies and IOC-sponsors - seemingly constituted the more attractive option in this situation. Here, the IOC's heavy dependence on the Olympic Games has to be considered. The Games are the organization's main source of income (International Olympic Committee, n.d.b) and virtually all its revenues stem from the Games either directly or indirectly. But - as has been outlined in this paper - democracies have become very likely to not see their bids through to the end. That means that the transaction costs of these bids and their high probability of becoming sunk costs for the IOC in case of a withdrawal, could potentially pose an existential threat to the IOC if it were left without a potential host city or if an elected host city should refuse to stage on short notice. Despite Innsbruck had stepped in as substitute host for Denver for the Winter Games in 1976, it is highly unlikely that a democratic country could fill such an opening nowadays because of the insecure and long-lasting process involving a large number of stakeholders depicted in Figure 2. An authoritarian state, on the other hand, might be inclined to step up if it were invited by the IOC since only one major choice would have to be taken involving considerably less relevant parties (Figure 2).

This shows that disadvantages resulting from the IOC's ties to authoritarian states can strategically be acceptable because they can be considered an insurance fee for a time without a potential host for an Olympic Games (i.e. if all potential hosts drop out of a bidding process or if a successful bidder eventually refuses to stage the event). In such an instance, the IOC would most likely be dependent on an authoritarian regime to come to its aide on short notice because of the long and transaction rich process in western democracies depicted in Figure 2. Since being left without a (potential) Olympic host would threaten the IOC's existence due to the financial importance of the event, it seems strategically viable for the organization to go to great lengths to protect its relationship with authori- tarian countries. Against the backdrop of transaction cost economics, it could thus be argued that taking the blame for not insisting on the strict enforcement of civil rights and freedom of press during the bidding process for 2022 or failing to severely punish systematic state-doping in Russia prior to the Games in 2016 must have been considered less costly by the IOC than losing an insurance for the Olympic Games and - because of its heavy financial dependency on the Games - ultimately the IOC itself.

A related consideration is applicable to the change of strategy in the bidding process for $2024 / 28$. Despite having conducted a bidding process for 2024 , the $I O C$ is now awarding the Games in 2028 as well. This strategic flexibility enabled the organization to attain two aims: On the one hand, it has gained considerable time before having to conduct the next bidding process for Summer Olympic Games. On the other, it has assured that after the Games in Tokyo in 2020, also the two following Summer Games will be staged in democratic countries. This could enable the IOC to conduct a long-term branding strategy geared towards lessening its perceived proximity to authoritarian countries. This should especially be possible because the next hosts, Tokyo, Paris, and Los Angeles, are very attractive destinations in rather stable democracies.

Concluding the paper, some limitations have to be pointed out. First of all, the analyses relate to specific observations and conclusions regarding recent developments connected to the Olympic Games and Olympic bidding processes. Consequently, it cannot be expected that all potential decisions, contracts, and transactions costs that can occur in the IOC's relations with democratic or authoritarian governments have been looked into. But since the aim of this paper was to specifically scrutinize developments and related ex ante transaction costs for the bidding process, this limitation is part of the research agenda. Moreover, transaction costs are not the only reason why an international organization upholds good working relations with a government - be it democratic or authoritarian. Personal acquaintances and preferences as well as other strategic considerations or influences than the ones that have been looked into in this paper are of central importance as well. For example, conquering new markets or broadening the fan base of specific sports or sport in general can also be strong motivators. This means that this paper is not to be understood as an exhaustive analysis of the IOC's strategic management of its relations to authoritarian or democratic governments but of one specific aspect of this relation.

\section{Funding}

The authors have no funding or support to report.

\section{Competing Interests}

The authors have declared that no competing interests exist. 


\section{Data Availability Statement}

All relevant data are within the paper.

\section{References}

Andranovich, G., Burbank, M. J., \& Heying, C. H. (2001). Olympic Cities: Lessons Learned from Mega-Event Politics. Journal of Urban Affairs, 23(2), 113-131. https://doi.org/10.1111/07352166.00079

Atkinson, G., Mourato, S., Szymanski, S., \& Ozdemiroglu, E. (2008). Are We Willing to Pay Enough to `Back the Bid'? Valuing the Intangible Impacts of London's Bid to Host the 2012 Summer Olympic Games. Urban Studies, 45(2), 419-444.

Barget, E., \& Gouguet, J.-J. (2007). The economic impact and social utility of the 2007 Rugby World Cup in France. Université de Limoges, Limoges.

Barrabi, T. (2015). Winter Olympics 2022 Host Candidate China, Kazakhstan's Human Right Records Draw Scrutiny, Concern. Retrieved from http://www.ibtimes.com/winter-olympics2022-host-candidates-china-kazakhstans-human-rightsrecords-draw-2032108

Carroll, R., \& Melander, I. (2017). Paris 2024 Olympics nearly assured as Los Angeles agrees to 2028 Games. Retrieved from https://www.reuters.com/article/us-olympics-los-angelesidUSKBN1AG235

Clarkson, M. B. E. (1995). A stakeholder framework for analysing and evaluating corporate social performance. Academy of Management Review, 20(1), 92-117.

Crook, J. (2013). Vienna says no to 2028 Olympic Games bid. Retrieved from http://www.insidethegames.biz/articles/1013307/vienna-says-no-to-2028-olympic-games-bid

Dampf, A. (2016). No Boston Olympics joins call for Rome 2024 bid referendum. Retrieved from http://www.boston.com/ sports/olympics/2016/01/14/no-boston-olympics-joinscall-for-rome-2024-bid-referendum

Donaldson, T., \& Preston, L. E. (1995). The Stakeholder Theory of the Corporation: Concepts, Evidence, and Implications. Academy of Management Review, 20(1), 65-92.

Freedom House. (2017). Freedom in the World 2017: Methodology. Retrieved from https://freedomhouse.org/report/ methodology-freedom-world-2017

Freeman, R. E. (2008). Strategic Management: A Stakeholder Approach. Boston: Pitman Press.

Goddard, E. (2013). Oslo residents vote in favour of 2022 Winter Olympic and Paralympic bid. Retrieved from http://www. insidethegames.biz/articles/1015939/oslo-residents-votein-favour-of-2022-winter-olympic-and-paralympic-bid

Guala, C. (2009). To bid or not to bid: public opinion before and after the Games. The case of the Turin 2006 Olympic Winter Games. In J. Kennell, C. Bladen, \& E. Booth (Eds.), The Olympic Legacy. People, Place, Enterprise. Proceedings of the first annual conference on Olympic Legacy 8 and 9 May 2008 (pp. 21-30). Greenwich: University of Greenwich.
Heisey, K. (2009). Estimating the Intangible Benefits of Hosting the 2016 Olympic and Paralympic Games for Potential Bid (Dissertation). Deutsche Sporthochschule Köln, Köln. Retrieved from http://esport.dshs-koeln.de/183/1/Kevin_Heisey_dissertation_final_version_dec_8.pdf

Heyne, M., \&Süssmuth, B. (2007). Hidden Value:Wohlfahrtsökonomische Effekte internationaler Sportgroßveranstaltungen: eine Betrachtung vom anderen Ende des ContingentValuation-Spektrums: Maradona- vs. Beckenbauer-Effekt. Schmollers Jahrbuch Zeitschrift für Wirtschafts- und Sozialwissenschaften, 127(4), 511-529.

Human Rights Watch. (2015). China/Kazakhstan: 2022 Games Major Test of Olympic Reforms: Olympic Committee Should Enforce Its New Rules. Retrieved from https://www.hrw.org/ news/2015/07/21/china/kazakhstan-2022-games-majortest-olympic-reforms

International Olympic Committee. (n.d.a). Olympic Games Candidature Process: All about the candidature process. Retrieved from https://www.olympic.org/all-about-thecandidature-process

International Olympic Committee. (n.d.b). Revenue Sources and Distribution. Retrieved from https://www.olympic.org/ ioc-financing-revenue-sources-distribution

International Olympic Committee. (n.d.c). Support and Protect Clean Athletes. Retrieved from https://www.olympic.org/ the-ioc/support-and-protect-clean-athletes

International Olympic Committee. (2014). IOC Latest News: Five bid cities submit Application Files to host 2022 Olympic Winter Games. Retrieved from http://www.olympic. org/news/five-bid-cities-submit-application-files-to-host2022-olympic-winter-games/227355

International Olympic Committee. (2017). IOC makes historic decision in agreeing to award 2024 and 2028 Olympic Games at the same time. Retrieved from https://www.olympic.org/news/ioc-makes-historic-decision-in-agreeing-toaward-2024-and-2028-olympic-games-at-the-same-time

Klein, P. G. (1998). New Institutional Economics. Retrieved from http://dx.doi.org/10.2139/ssrn.115811

Könecke, T., Schubert, M., \& Preuß, H. (2016). (N)Olympia in Germany? An analysis of the referendum against Munich 2022. Sportwissenschaft, 46(1), 15-24. https://doi.org/10.1007/ s12662-015-0384-X

Livingstone, R. (2016). Budapest 2024 Olympic Bid Opponent Spins Question To Get New Referendum Approved. Retrieved from http://gamesbids.com/eng/featured/budapest-2024-olympic-bid-opponent-spins-question-to-getnew-referendum-approved/

Mackay, D. (2013). Barcelona will not bid for 2022 Winter Olympics and Paralympics, Mayor concedes. Retrieved from https://www.insidethegames.biz/articles/1016562/barcelonawill-not-bid-for-2022-winter-olympics-and-paralympicsmayor-concedes

Magistrat der Stadt Wien. (2013). Wiener Volksbefragung 2013: Endergebnis der Stadtwahlbehörde. Retrieved from https:// www.wien.gv.at/vbefergeb/internet/ 
Marca.com. (2011). Se disuelve el consorcio olímpico Zaragoza-Pirineos 2022: Barcelona se queda como única candidatura olímpica. Retrieved from http:// www.marca.com/2011/11/07/mas_deportes/otros_deportes/1320699392.html

Moore, J. (2015). When Denver rejected the Olympics in favour of the environment and economics: Colorado's biggest city won the bid to host the 1976 Winter Games, but its citizens decided they had other priorities. Retrieved from https:// www.theguardian.com/sport/blog/2015/apr/07/whendenver-rejected-the-olympics-in-favour-of-the-environment-and-economics

Morgan, L. (2017). Budapest City Assembly votes to withdraw Olympic bid. Retrieved from http://www.insidethegames. biz/articles/1047588/budapest-city-assembly-votes-towithdraw-olympic-bid

New York Times. (2016). Rome's Mayor Won't Support 2024 Olympic Bid. Retrieved from http://www.nytimes. com/2016/09/22/sports/olympics/rome-summer-games2024-bid.html?_r=0

News.at. (2006). Olympia 2014: Genau 60 Prozent der Salzburger stimmten für Bewerbung! Retrieved from https://www. news.at/a/olympia-2014-genau-60-prozent-salzburger-bewerbung-108859

Pavitt, M. (2016). Budapest 2024 claim bid has strong support as motion for citywide referendum receives initial approval. Retrieved from http://www.insidethegames.biz/ articles/1042373/budapest-2024-claim-bid-has-strongsupport-as-motion-for-citywide-referendum-receives-initial-approval

Preuss, H. (2008). The Olympic Games: Winners and Losers. In B. Houlihan (Ed.), Sport and society. A student introduction (2nd ed., pp. 415-438). Los Angeles: SAGE.

Preuss, H. (2013). Olympische Spiele der Neuzeit als Wirtschaftsfaktor - Wer profitiert von den Olympischen Spielen? In W. Höfling, J. Horst, \& M. Nolte (Eds.), Sport - Recht - Gesellschaft: Vol. 4. Olympische Spiele (pp. 27-56). Tübingen: Mohr Siebeck.

Preuss, H., \& Solberg, H. A. (2006). Attracting Major Sporting Events: The Role of Local Residents. European Sport Management Quarterly, 6(4), 391-411.

Sam, M. P., Batty, R., \& Dean, R. G. (2005). A Transaction Cost Approach to Sport Sponsorship. Sport Management Review, 8(1), 1-17. https://doi.org/10.1016/S1441-3523(05)70030-9

The Economist Intelligence Unit. (2015). Democracy Index 2015: Democracy in an age of anxiety. Retrieved from https://www.yabiladi.com/img/content/EIU-DemocracyIndex-2015.pdf

Thomson Reuters. (2014). Lviv drops 2022 bid, targets 2026 Games: IOC. Retrieved from http://www.reuters.com/article/us-olympics-ukraine-bid-idUSKBNOF500Q20140630

Williamson, O. E. (1981). The Economics of Organization: The Transaction Cost Approach. American Journal of Sociology, 87(3), 548-577. Retrieved from http://www.jstor.org/stable/2778934
Williamson, O. E. (1994). Transaction cost economics. In N. J. Smelser \& R. Swedberg (Eds.), The handbook of economic sociology (pp. 77-107). Princeton, New York: Russell Sage Foundation. 